\title{
Different tolerances of jellyfish ephyrae (Aurelia sp. 1) and fish larvae (Paralichthys olivaceus) to nutrient limitations
}

\author{
Lei Chen ${ }^{1,3}$, Chaolun $\mathrm{Li}^{1,2,3, *}$ \\ ${ }^{1}$ Key Laboratory of Marine Ecology and Environmental Sciences, Institute of Oceanology, Chinese Academy of Sciences, \\ 7 Nanhai Road, Qingdao 266071, PR China \\ ${ }^{2}$ Laboratory for Marine Ecology and Environmental Science, \\ Qingdao National Laboratory for Marine Science and Technology, Qingdao 266071, PR China \\ ${ }^{3}$ University of Chinese Academy of Sciences, 19 Yuquan Road, Beijing 100049, PR China
}

\begin{abstract}
Nutrient imbalance - a mismatch in nutrient ratios between the available food supply and the demands of consumers - has the potential to be transported up food chains, exposing higher trophic-level organisms to nutrient limitations. We performed experiments to estimate the tolerance of jellyfish ephyrae (Aurelia sp. 1) and fish larvae (Paralichthys olivaceus) to nutrient limitations, and analyzed their growth, survival, and elemental homeostasis. As the primary consumer, rotifers Brachionus plicatilis exhibited the lowest amino acid content but the highest fatty acid content in a P-limited treatment. Among the secondary consumers, nutrient limitations (especially P limitation) had significantly negative effects on the growth of $P$. olivaceus larvae, but no significantly negative effects on Aurelia sp. 1 ephyrae. The 10th percentile mortality time of Aurelia sp. 1 ephyrae was much longer than that of $P$. olivaceus larvae. In terms of elemental homeostasis, Aurelia sp. 1 ephyrae showed a greater ability to maintain constant chemical composition in their bodies than $P$. olivaceus larvae. Additionally, growth and survival of $P$. olivaceus larvae could be negatively affected by the reduction of amino acid contents (but not fatty acids) in their nutrient-limited food. These results indicate that Aurelia sp. 1 ephyrae could be more competitive than $P$. olivaceus larvae with respect to tolerance of nutrient limitations, and, thus, elemental imbalances may favor increases in jellyfish in some eutrophication regions.
\end{abstract}

KEY WORDS: Ecological stoichiometry $\cdot$ Phosphorus limitation · Nitrogen limitation · Jellyfish ephyrae · Fish larvae

\footnotetext{
${ }^{*}$ Corresponding author: lcl@qdio.ac.cn
}

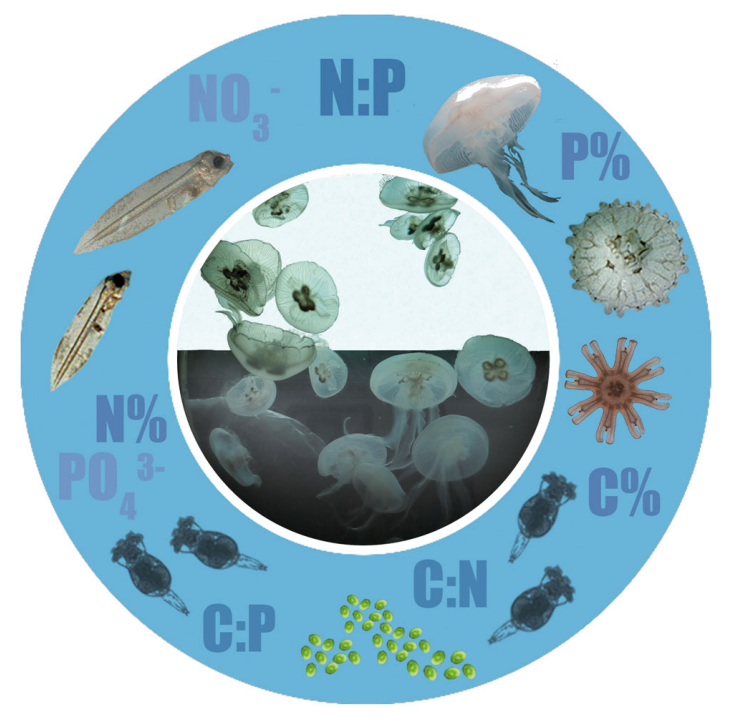

Jellyfish ephyrae could be more competitive than fish larvae under nutrient-limited conditions.

Graphic: Lei Chen and Chaolun $\mathrm{Li}$

\section{INTRODUCTION}

Eutrophication, defined as 'an increase in the rate of supply of organic matter to an ecosystem' (Nixon 1995), is a major global pollution problem (Howarth et al. 2002). It is often connected with a reduction in the size of the zooplankton community (Uye 1994), and low dissolved oxygen levels (hypoxia) (e.g. Breitburg et al. 2003), which are thought to be more detrimental to fish than to jellyfish (Purcell \& Arai 2001).

() The authors 2017. Open Access under Creative Commons by Attribution Licence. Use, distribution and reproduction are unrestricted. Authors and original publication must be credited. 
Due to these factors, eutrophication could benefit jellyfish over fish at potentially a regional scale (Purcell et al. 2007). Additionally, eutrophication is also associated with increased nutrient concentrations and altered nutrient ratios (from the Redfield ratio; Nixon 1995, Arai 2001). This can result in nutrient imbalances in planktonic food webs, thus causing a mismatch between nutrient supply and demand in higher trophic-level organisms, including jellyfish and fish. But whether this imbalance would promote jellyfish population increases in eutrophic areas remains unclear.

Ecological stoichiometry offers a new perspective in the study of eutrophication (Sterner \& Elser 2002). It is generally accepted that the stoichiometry of primary producers is highly affected by nutrient conditions (Rhee 1978, Goldman et al. 1979, Sterner \& Elser 2002, Klausmeier et al. 2004b, Hall et al. 2005). For example, the molar N:P ratio of Scenedesmus spp. closely tracks the variations in N:P supply ratios (Rhee 1978). Animals usually maintain relative homeostasis (Elser et al. 2000); however, herbivores that encounter low-quality food sources experience difficulty maintaining strict homeostasis when feeding on food limited in $\mathrm{P}$ or $\mathrm{N}$ because of the costs of homeostasis, and their nutrient contents change accordingly (Elser et al. 2001, Van Nieuwerburgh et al. 2004, Malzahn et al. 2010). Increasing research has focused on the interface between herbivores and carnivores. A number of studies have shown that the effects of food source quality in the primary producer-herbivore interface could be transported up the food chain, and some carnivores also face the problem of nutritional imbalances, leading to a mismatch between supply and demand (e.g. Malzahn et al. 2007, Schoo et al. 2012, 2014, Lesniowski et al. 2015). Nevertheless, this effect on carnivores varies according to species. In lobster larvae (Homarus gammarus), even subtle $\mathrm{N}$ and $\mathrm{P}$ limitations could cause negative effects on their growth conditions (Schoo et al. 2014), whereas the condition of ctenophores Pleurobrachia pileus fed P-limited food sources was better than the condition of ctenophores in a nutrient-sufficient treatment, which was not expected (Schoo et al. 2010). With regard to fish larvae, Malzahn et al. (2007) observed that the food quality of primary producers significantly affected the condition of larval Baltic herring Clupea harengus, and a P-limited food chain resulted in significantly worse conditions compared with the N-limited and nutrient-sufficient food chain.

Moreover, it is unclear whether nutrient stoichiometry (e.g. C:N:P ratios) or biochemical compounds (e.g. fatty acids [FA] and amino acids) are better correlated with the life-history traits of organisms (e.g. growth and reproduction) and which factor would be a better predictor of food quality (Andersen et al. 2004, Malzahn et al. 2010, Chen \& Li 2014). Obviously, C:N:P ratios have been widely measured (Malzahn et al. 2010) and are not the only factor that determines food quality (Reitan et al. 1997). A number of studies have focused on FA (e.g. MüllerNavarra 1995, Malzahn et al. 2007) since they are biologically important as energy reserves, membrane components, and hormones (Kattner et al. 2007). Meanwhile, amino acids also play an important role in the nutritive aspect of an organism. They are crucial building blocks for the synthesis of proteins; thus, there is high demand for amino acids during growth (Conceição et al. 2003). In addition, amino acids are considered to be important sources in the production of energy during the larval stage (Rønnestad et al. 1999), which contributes to the high demand for dietary amino acids. Although amino acid content may be a good predictor of food quality, to our knowledge, few studies have focused on this aspect of carnivore prey quality under nutrientlimited conditions.

To address these gaps, we performed experiments to test the hypotheses that: (1) compared to fish, jellyfish have higher tolerances to the nutrient imbalances that are potentially caused by eutrophication, and (2) under nutrient-limited conditions, amino acid content is an important factor determining food quality.

Aurelia sp. 1 ephyrae and Paralichthys olivaceus larvae were selected as the subjects of our study, because Aurelia sp. 1 is one of the main blooming jellyfish species in coastal waters, and $P$. olivaceus is an economically important species of fish. In addition, Aurelia sp. 1 ephyrae and P. olivaceus larvae could be observed during the same period in the same area (e.g. Jiaozhou Bay, China; from April to June) (Wu et al. 1987, Wan \& Zhang 2012). Moreover, jellyfish ephyrae derived from strobilating polyps could be considered as a critical life stage (Ishii et al. 2004), just like newly hatched larvae in fish. In this study, the effects of food of varying quality (nutrientsufficient, P-limited, and N-limited) on the condition of Aurelia sp. 1 ephyrae and P. olivaceus larvae were investigated. Our main objectives were to (1) estimate the tolerance of Aurelia sp. 1 ephyrae and P. olivaceus larvae to nutrient limitations based on their growth, survival, and elemental homeostasis, and (2) explore whether FA content or amino acid content was a better predictor of food quality under nutrientlimited conditions. 


\section{MATERIALS AND METHODS}

\section{Primary producer}

Stock cultures of the green algae Chlorella vulgaris were cultivated in $C$. vulgaris culture medium (625 $\mu \mathrm{M} \mathrm{NH}_{4} \mathrm{NO}_{3}, 28.7 \mu \mathrm{M} \mathrm{K}_{2} \mathrm{HPO}_{4}{ }^{3-}$, and $2041.3 \mu \mathrm{M}$ ferric citrate). The seawater used in the experiment was collected from Huiquan Bay in Qingdao, China. Prior to the experiment, the seawater was filtered through a sterile $0.2 \mu \mathrm{m}$ filter, heated to a boil, cooled, and stored until use. This sterile seawater consisted of $9.39 \mu \mathrm{M} \mathrm{NO}_{3}{ }^{-}, 0.38 \mu \mathrm{M} \mathrm{PO}_{4}{ }^{3-}, 0.53 \mu \mathrm{M}$ $\mathrm{NO}_{2}{ }^{-}$, and $2.72 \mu \mathrm{M} \mathrm{NH}_{4}{ }^{+}$. All of the algal treatments were maintained at $20 \pm 0.5^{\circ} \mathrm{C}$, under a $12 \mathrm{~h}$ light: $12 \mathrm{~h}$ dark cycle and light intensity of 4000 lux.

The nutrient-sufficient treatment ('Full' or ' $-\mathrm{F}$ ') consisted of seawater that was culture-enriched with $740.4 \mu \mathrm{M} \mathrm{NO}_{3}{ }^{-}-\mathrm{N}, 661.1 \mu \mathrm{M} \mathrm{NH}{ }_{4}{ }^{+}-\mathrm{N}$, and $29.3 \mu \mathrm{M}$ $\mathrm{PO}_{4}{ }^{3-}-\mathrm{P}(\mathrm{N}: \mathrm{P}$ ratio $=48)$. The $\mathrm{N}$-limited treatment (or ' $-\mathrm{N}^{\prime}$ ) was obtained by reducing the concentrations of $\mathrm{NO}_{3}{ }^{-}-\mathrm{N}$ and $\mathrm{NH}_{4}{ }^{+}-\mathrm{N}$ to $115.4 \mu \mathrm{M}$ and $36.1 \mu \mathrm{M}(\mathrm{N}: \mathrm{P}=$ 5), respectively. In the P-limited treatment (or ' $-\mathrm{P}$ '), the addition of $\mathrm{K}_{2} \mathrm{HPO}_{4}{ }^{3-}$ was omitted and the concentration of $\mathrm{PO}_{4}{ }^{3-}-\mathrm{P}$ was reduced to $0.6 \mu \mathrm{M}(\mathrm{N}: \mathrm{P}=$ 2336). This high value of the N:P ratio (2336) was intended to create nutrient gradients in the rotifers in our study similar to those in natural zooplankton populations (Kütter et al. 2014), as the rotifers were able to maintain their elementary homeostasis to some extent. The ionic strength in the nutrient-limited treatments was maintained by the addition of $\mathrm{KCl}$. Therefore, the algae of the 2 limitation treatments could only utilize the natural $\mathrm{P}$ or $\mathrm{N}$ sources present in the seawater, with the other nutrient added in excess, ensuring that the desired nutrient was limiting (Boersma et al. 2009, Malzahn et al. 2010, Schoo et al. 2014). Preliminary tests showed that nutrient composition (\% of dry mass [DM]: $\% \mathrm{C}, \% \mathrm{~N}$, and $\% \mathrm{P}$ ) and molar ratios $(\mathrm{C}: \mathrm{N}, \mathrm{C}: \mathrm{P}$, and $\mathrm{N}: \mathrm{P})$ of $C$. vulgaris (Table 1) changed significantly (all $\mathrm{p}<0.05$; Table 1 ) under the experimental conditions after a growth period of $5 \mathrm{~d}$. Algae grown under the $\mathrm{N}$-limited condition showed a lower value of N:P than the Full treatment (11.49 for $-\mathrm{N}$ and 27.54 for $-\mathrm{F}_{\text {; }}$ Table 1), whereas the P-limited algae showed a higher value of N:P (71.58 for $-\mathrm{P}$; Table 1$)$. These conditions allowed Brachionus plicatilis to feed on grown algae having different nutritional content. To ensure the quality and constant supply of algae, new cultures of the 3 treatments were inoculated every other day and harvested after $5 \mathrm{~d}$.

\section{Primary consumer}

B. plicatilis were hatched from dormant eggs in shallow dishes containing sterile seawater. All of the treatments were maintained at $20 \pm 0.5^{\circ} \mathrm{C}$ under a $12 \mathrm{~h}$ light:12 h dark cycle and light intensity of 4000 lux.

Newly born $B$. plicatilis (up to $2 \mathrm{~h}$ old) were divided into 9 groups and transferred to $1 \mathrm{l}$ glass beakers at a concentration of 5 individuals $\mathrm{ml}^{-1}$. Three treatments $(-\mathrm{F},-\mathrm{N}$, and $-\mathrm{P}) \times 3$ replicates were performed. To prevent food-quantity effects, $B$. plicatilis were fed the same concentration of algae $\left(3 \mu \mathrm{m} \mathrm{C} \mathrm{ml}{ }^{-1}\right)$, and algal food was refreshed every other day. After $6 \mathrm{~d}$ of cultivation and $12 \mathrm{~h}$ of starvation, rotifers were filtered on GF/F filters (precombusted and acidwashed) and then analyzed for nutrient composition $(\mathrm{C}, \mathrm{N}$, and $\mathrm{P})$ and nutritional composition (FA and amino acids).

Because of the low biomass of B. plicatilis, large numbers were needed to feed the secondary consumers. However, the dormant eggs of the rotifers could not meet the consumers' needs. To ensure a sufficient food supply, dormant eggs were hatched and cultivated in a $15 \mathrm{l}$ container under the $-\mathrm{F}$ condition, and approximately 75000 rotifers were filtered out every other day. After the rotifers were starved for $24 \mathrm{~h}$, they were transferred to 3 glass beakers (5 1 size) and cultivated under the 3 nutrient conditions. After a period of approximately $8 \mathrm{~d}$, rotifers were harvested as food for the secondary consumers.

Table 1. Nutrient composition (\% of dry mass: $\% \mathrm{C}, \% \mathrm{~N}$, and $\% \mathrm{P}$ ) and molar ratios (C:N, C:P, and N:P) of Chlorella vulgaris grown under nutrient-sufficient ('Full'), N-limited, and P-limited conditions after $5 \mathrm{~d}$. Values represent the means of 3 replicate samples and are listed as mean \pm SD. Significant differences (Tukey's HSD test, $p<0.05$ ) among the 3 treatments are indicated by different superscripted lowercase letters

\begin{tabular}{|c|c|c|c|c|c|c|}
\hline & $\% \mathrm{C}$ & $\% \mathrm{~N}$ & $\% \mathrm{P}$ & $\mathrm{C}: \mathrm{N}$ & $\mathrm{C}: \mathrm{P}$ & $\mathrm{N}: \mathrm{P}$ \\
\hline Full & $13.12 \pm 1.51^{\mathrm{a}}$ & $2.36 \pm 0.36^{\mathrm{a}}$ & $0.19 \pm 0.03^{\mathrm{a}}$ & $6.50 \pm 0.22^{\mathrm{a}}$ & $178.05 \pm 40.40^{\mathrm{a}}$ & $27.54 \pm 6.95^{\mathrm{a}}$ \\
\hline N-limited & $18.04 \pm 2.01^{b}$ & $1.57 \pm 0.19^{b}$ & $0.30 \pm 0.05^{\mathrm{b}}$ & $13.64 \pm 2.98^{\mathrm{b}}$ & $157.33 \pm 38.74^{\mathrm{a}}$ & $11.49 \pm 0.81^{\mathrm{b}}$ \\
\hline P-limited & $20.81 \pm 1.51^{\mathrm{b}}$ & $1.83 \pm 0.04^{\mathrm{ab}}$ & $0.06 \pm 0.01^{\mathrm{c}}$ & $13.25 \pm 1.04^{\mathrm{b}}$ & $946.90 \pm 238.32^{b}$ & $71.58 \pm 17.67^{\circ}$ \\
\hline
\end{tabular}




\section{Secondary consumers}

For fish larvae, Paralichthys olivaceus eggs from the same parents were obtained from a commercial hatchery. Eggs were incubated at $15^{\circ} \mathrm{C}$. During the $2 \mathrm{~d}$ incubation, water temperature was raised by $1.5^{\circ} \mathrm{C} \mathrm{d}^{-1}$ to the experimental temperature of $18^{\circ} \mathrm{C}$. All of the treatments were subjected to a $12 \mathrm{~h}$ light: $12 \mathrm{~h}$ dark cycle and light intensity of 4000 lux. Terramycin ( $3 \mathrm{ppm}$ the first time, thereafter $5 \mathrm{ppm}$ ) was added to all of the treatments every other day to control epizootics (Fukuda et al. 1996). Swimming larvae without yolk sacs were divided into 9 groups (3 treatments $\times 3$ replications) and transferred to containers filled with $4 \mathrm{l}$ filtered seawater at a concentration of 5 fish $\mathrm{l}^{-1}$. The larvae of the 3 treatments were fed the same concentration of rotifers (10 individuals $\mathrm{ml}^{-1}$ except for 7 individuals $\mathrm{ml}^{-1}$ on the first day) grown under 3 nutritional conditions every other day. Before feeding, any remaining rotifers were removed and the water was refreshed.

For jellyfish ephyrae, Aurelia sp. 1 ephyrae were released from stock-cultured sessile polyps in the laboratory at the Institute of Oceanology, Chinese Academy of Sciences in Qingdao, China. Polyps were fed with newly hatched Artemia nauplii but were not fed for $24 \mathrm{~h}$ before the collection of ephyrae. Every 50 newly released ephyrae $(<24 \mathrm{~h}$, bell diameter was approximately $3 \mathrm{~mm}$ ) were placed in a container with 51 filtered seawater. Nine containers were assigned to 3 treatments $(-\mathrm{F},-\mathrm{N}$, and $-\mathrm{P})$ and replicated 3 times. The experiments were conducted at $18^{\circ} \mathrm{C}$. Ephyrae in the 3 treatments were fed rotifers (10 individuals $\mathrm{ml}^{-1}$ ) grown under the 3 nutritional conditions. Every other day, any remaining rotifers were removed and the water was refreshed. Then newly cultured rotifers under 3 nutritional conditions were added to the containers.

Length and bell diameter were used as measurements of body size. For $P$. olivaceus larvae, length was measured from the tip of the snout to the tip of the longer lobe of the caudal fin (total length), using a calibrated Vernier caliper every other day. For Aurelia sp. 1 ephyrae, bell diameter was the distance between the edges of the 2 opposite lappets, and was measured using the ocular micrometer of a dissecting microscope (ZEISS Stemi SV 11) every $3 \mathrm{~d}$. The 10 th percentile mortality time (MT10) was defined as the time span at which $10 \%$ of the larvae died or the ephyrae deformed under 3 nutritional conditions. Larvae that showed no movement after several stirrings of seawater using a pipette were judged to be dead. Ephyrae that were reduced to a rod-like oral core were judged to be deformed. Meanwhile, the morphological changes of the secondary consumers and swim speed of the $P$. olivaceus larvae were also observed during the experiment.

Once the secondary consumers in the 2 limitation treatments reached MT10, the organisms in all 3 treatments were harvested. Ten to 15 individuals of Aurelia sp. 1 ephyrae and 4 to 5 individuals of $P$. olivaceus larvae were collected from each container to analyze $\mathrm{C}$ and $\mathrm{N}$ content, and $\mathrm{P}$ content, respectively. Additionally, the newly released $P$. olivaceus larvae (without yolk sacs) and the Aurelia sp. 1 ephyrae at $t_{0}$ (start of the experiment) in each container were collected to determine $\mathrm{C}$ and $\mathrm{N}$ content and $\mathrm{P}$ content, respectively. All organisms were collected by filtration through Whatman GF/F filters (pre-combusted, washed, and dried), stored at $-80^{\circ} \mathrm{C}$, freeze-dried, weighed, and kept in a desiccator until further analysis.

\section{Analytical procedures}

For the analysis of $\mathrm{C}$ and $\mathrm{N}$ contents, samples were coated by tin boats and measured using an elemental analyzer (Elementar Company). To analyze P content, samples were weighed and digested with $5 \mathrm{ml}$ nitric acid and $1 \mathrm{ml}$ perchloric acid. The temperature of heating plate was increased from $175^{\circ} \mathrm{C}$ to $220^{\circ} \mathrm{C}$ to dry out the acid solution. Nitric acid (1:1) was added to the sample after the solution was cooled to room temperature. The samples were then rinsed with Milli-Q deionized water and then transferred to $25 \mathrm{ml}$ specimen tubes. The blank sample was made in the same way so that the $\mathrm{P}$ content of Whatman $\mathrm{GF} / \mathrm{F}$ filters we used (pre-combusted and washed) could be measured. Then all samples with a series of standard solution $\left(0,1,5,10,20,50 \mu \mathrm{g}^{-1}\right)$ and $20 \mu \mathrm{g}$ $\mathrm{l}^{-1} \mathrm{Rh}$ internal standard solution were analyzed using an ICP plasma emission spectrometer (Thermo Fisher Scientific, iCAP-Qc).

To analyze amino acid content, approximately $20 \mathrm{mg}$ of the samples was placed in an ampoule, $10 \mathrm{ml} 6 \mathrm{~mol} \mathrm{l}^{-1} \mathrm{HCl}$ and $\mathrm{N}_{2}$ were added, and then the ampoule was sealed and placed in a $110^{\circ} \mathrm{C}$ drying oven for $24 \mathrm{~h}$ of hydrolyzation. Subsequently, $0.02 \mathrm{~mol} \mathrm{l}^{-1}$ of $\mathrm{HCl}$ was added to a volume of $10 \mathrm{ml}$. The amino acid content was detected by HPLC using phenylisothiocyanate as the reagent. An Agilent 1100 liquid chromatograph with a Venusil-AA (4.6 × $250 \mathrm{~mm}, 5 \mu \mathrm{m})$ column at a temperature of $40^{\circ} \mathrm{C}$, detection wavelength of $254 \mathrm{~nm}$, mobile phase A of $0.1 \mathrm{M}$ sodium acetate ( $7 \%$ acetonitrile), mobile phase B of $80 \%$ acetonitrile, and gradient elution of $1 \mathrm{ml}$ 
$\min ^{-1}$ was used. FA were measured as fatty acid methyl esters (FAMEs) after the method described by Liu et al. (2011).

\section{Statistical analysis}

To estimate the ability of the secondary consumers to maintain homeostasis, the homeostatic regulation coefficient $(H)$ was calculated according to the following equation (Sterner \& Elser 2002):

$$
y=C x^{\frac{1}{H}}
$$

$H$ was calculated by linearizing the equation above using logarithms (Sterner \& Elser 2002):

$$
\log (y)=\log (c)+\frac{\log (x)}{H}
$$

where $y$ is the stoichiometry of Aurelia sp. 1 ephyrae or $P$. olivaceus larvae, $x$ is the stoichiometry of their food source (rotifers), and $c$ is a constant. Stoichiometry here means the ratio of the elements or element content (\% of DM) (e.g. N:P, \% P, etc.). Linear regressions were fitted, and the parameters of these regressions were used to assess the homeostatic responses of the secondary consumers.

The nutrient composition ( $\%$ of DM: $\% \mathrm{C}, \% \mathrm{~N}$, and $\% \mathrm{P}$ ) and molar ratios (C:N, C:P, and $\mathrm{N}: \mathrm{P}$ ) of $C$. vulgaris, B. plicatilis, P. olivaceus, and Aurelia sp. 1 as well as the nutritional composition (FA, amino acids) of $B$. plicatilis were statistically analyzed using a 1-way ANOVA, with treatment used as the independent variable. Tukey's HSD was used as the post hoc test. Kruskal-Wallis $H$ test was used if the data after being $\ln (x+1)$-transformed did not approach normality (Kolmogorov-Smirnov test) or homoscedasticity of variance (Levene's test). A repeated-measures ANOVA was used to test the effects of nutrient conditions on the changes in length of $P$. olivaceus and bell diameter of Aurelia sp. 1, with treatment and time as the variables. Fisher's HSD was performed as the post hoc test. All of the statistical tests were conducted using the software SPSS 19.0 and Origin 9.0.

\section{RESULTS}

\section{Primary consumer}

Rotifers (Fig. 1) reared on P-limited algae showed the lowest content of $\mathrm{P}(0.51 \%$; Fig. $1 \mathrm{c})$, and the lowest contents of $\mathrm{C}$ and $\mathrm{N}(30.50 \% \mathrm{C}$ and $3.86 \%$

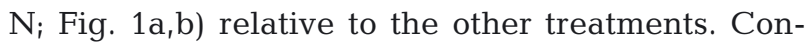
trary to our expectations, the $\mathrm{N}$ content of consumers in the $-\mathrm{N}$ treatment was not the lowest, and it was greater than that of the $-\mathrm{P}$ treatment $(6.74 \%$

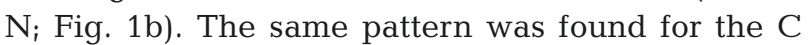
and $\mathrm{P}$ contents $(36.69 \% \mathrm{C}$ and $0.59 \% \mathrm{P}$; Fig. 1a,c). The $-\mathrm{F}$ treatment provided the highest contents of C, $\mathrm{N}$, and $\mathrm{P}(43.91 \% \mathrm{C}, 8.45 \% \mathrm{~N}$, and $0.73 \% \mathrm{P}$; Fig. 1a-c).

The same pattern was observed for total amino acid content. The $-\mathrm{P}$ treatment showed the significantly lowest value (1-way ANOVA, $F_{2,6}=46.76, \mathrm{p}<$ 0.01; Table 2, Fig. 2). However, the FA content exhibited opposite results. The $-\mathrm{P}$ treatment showed the highest concentration of total FA ( $\mu \mathrm{g} \mathrm{mg} \mathrm{DM} \mathrm{DM}^{-1}$ ), highest concentration and proportion ( $\%$ total FA content) of total unsaturated FA, lowest proportion of total saturated FA, highest proportion of $\omega 3 \mathrm{FA}$, and the highest value of the $\omega 3 \mathrm{FA}: \omega 6 \mathrm{FA}$ ratio (all $\mathrm{p}<0.05$; Table 3, Fig. 2).

In summary, the -P treatment provided the highest content in terms of FA content, although these results were the opposite with regard to the nutrient composition and total amino acids. A comparison of the different effects according to the physiological indicators of secondary consumers (growth, MT10, and elemental homeostasis) was useful for determining the factors that have more important effects on food quality.

\section{Secondary consumers}

Growth

Significant differences were observed in the length of the Paralichthys olivaceus larvae among the 3 treatments during the experimental period (2-way repeated-measures ANOVA, $F_{3,40}=526.43, \mathrm{p}<0.01$; Fig. 3a). The $-F$ treatment presented the longest larvae, followed by the $-\mathrm{N}$ treatment and the $-\mathrm{P}$ treatment, which had much smaller values. The morphological status on the last day of the experiment showed obvious differences among the 3 treatments (Fig. 4). The larvae in the $-\mathrm{F}$ treatment qualitatively swam faster and had more developed digestive systems (Fig. 4) than those in the other treatments, whereas the $-\mathrm{P}$ treatment produced the thinnest and weakest larvae (Fig. 4), which qualitatively swam the slowest.

The Aurelia sp. 1 ephyrae bell diameter presented a different pattern from that of the larval length 

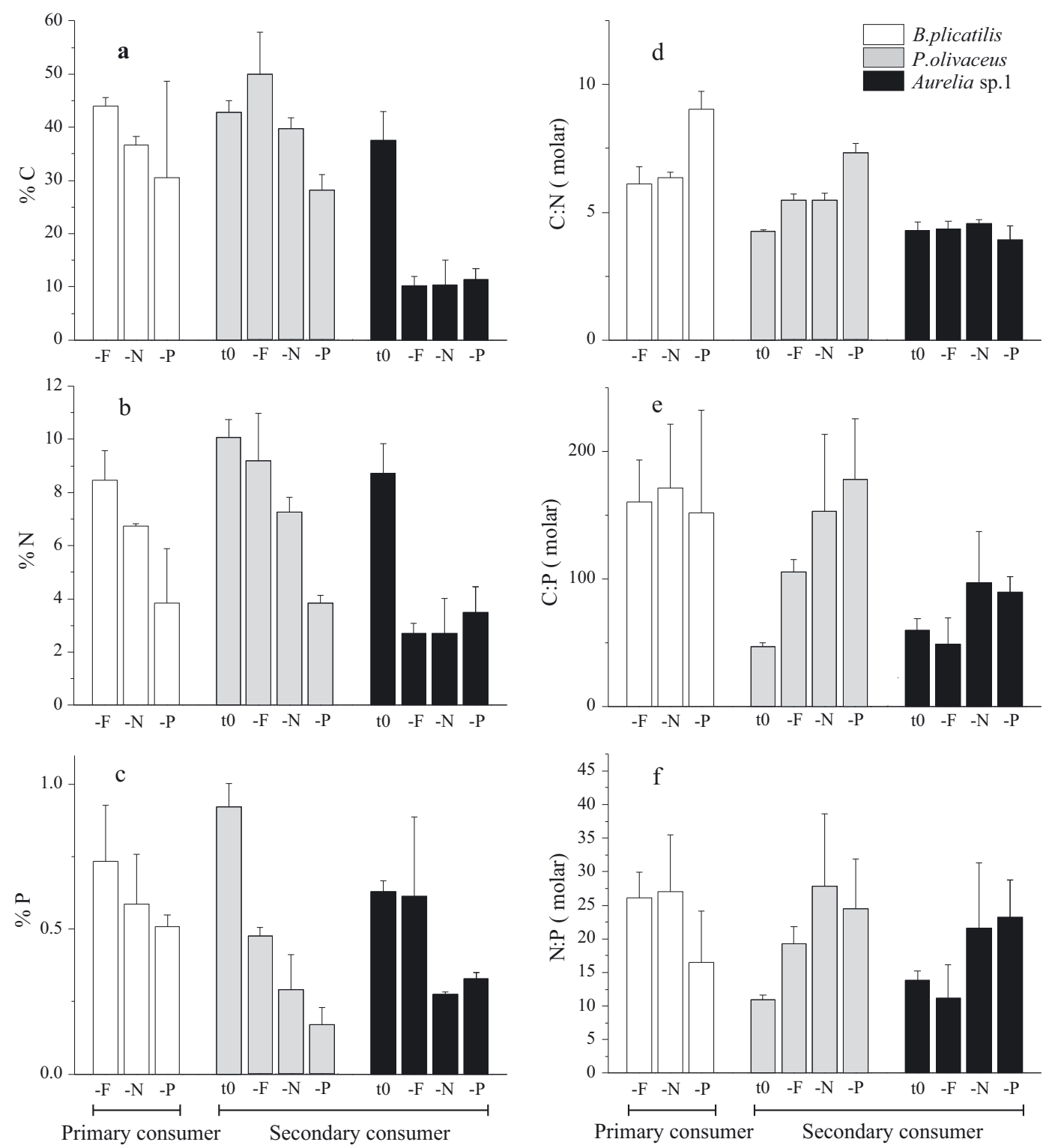

Fig. 1. $(\mathrm{a}-\mathrm{c})$ Nutrient composition (\% of dry mass: $\% \mathrm{C}, \% \mathrm{~N}$, and $\% \mathrm{P})$ and $(\mathrm{d}-\mathrm{f})$ molar ratios $(\mathrm{C}: \mathrm{N}, \mathrm{C}: \mathrm{P}$, and $\mathrm{N}: \mathrm{P})$ of primary $($ Brachionus plicatilis) and secondary consumers (Paralichthys olivaceus larvae and Aurelia sp. 1 ephyrae) at $t_{0}$ (start of the experiment) and when fed food of different nutrient conditions (Full or ' $-\mathrm{F}^{\prime}$, N-limited or ' $-\mathrm{N}^{\prime}$, P-limited or '-P'). Error bars: SD. Note different $y$-axis scales

(Fig. 3b). Significant differences were not detected between the $-\mathrm{F}$ treatment and the $-\mathrm{P}$ treatment (HSD, $\mathrm{p}>0.05$ ), and the $-\mathrm{N}$ treatment always produced a greater bell diameter than the other treatments (HSD, $\mathrm{p}<0.01$; Fig. 3b). In terms of the morphological status, obvious differences were not observed among the treatments during the experimental period, although the ephyrae under the $-\mathrm{N}$ condition showed more rapid morphological changes, with flat circular bells and 4 conspicuous central gastric pouches observed on the $17^{\text {th }}$ day (Fig. 4).

\section{MT10}

The death rate of $P$. olivaceus larvae and the deformity rate of Aurelia sp. 1 ephyrae both showed the highest values in the $-\mathrm{P}$ treatment and the lowest values under the $-\mathrm{F}$ condition (Fig. $5 \mathrm{a}, \mathrm{b}$ ). In the $-\mathrm{P}$ treatment, MT10 was estimated at $5.6 \mathrm{~d}$ for larvae and $12 \mathrm{~d}$ for ephyrae. Under the $-\mathrm{N}$ condition, the MT10 estimates were $7 \mathrm{~d}$ for larvae and $16.1 \mathrm{~d}$ for ephyrae. These results implied that the MT10 of Aurelia sp. 1 ephyrae was much longer than that of $P$. olivaceus larvae in both limitation treatments (Fig. 5a,b). 
Table 2. Amino acid composition of Brachionus plicatilis reared on phytoplankton Chlorella vulgaris grown under 3 different nutrient conditions. Values represent the means of 3 replicate samples and are listed in mg per $g$ dry mass (DM) (mean \pm SD) and $\%$ of total amino acid content (mean $\pm \mathrm{SD}$ ). Significant differences (Tukey's HSD test or Kruskal-Wallis $H$ test, $\mathrm{p}<0.05$ ) among the 3 treatments indicated by different superscripted lowercase (for DM) or uppercase letters (for \% of total amino acid content)

\begin{tabular}{|c|c|c|c|c|c|c|}
\hline \multirow[t]{2}{*}{ Amino acid } & \multicolumn{2}{|c|}{ Full } & \multicolumn{2}{|c|}{ N-limited } & \multicolumn{2}{|c|}{ P-limited } \\
\hline & $\operatorname{mg~g~} \mathrm{DM}^{-1}$ & $\%$ of total & $\operatorname{mg~g~} \mathrm{DM}^{-1}$ & $\%$ of total & $\operatorname{mg~g~} \mathrm{DM}^{-1}$ & $\%$ of total \\
\hline \multicolumn{7}{|l|}{ Essential } \\
\hline Threonine & $2.13 \pm 0.12^{\mathrm{a}}$ & $4.30 \pm 0.15^{\mathrm{A}}$ & $1.77 \pm 0.12^{\mathrm{b}}$ & $4.09 \pm 0.17^{\mathrm{AB}}$ & $0.95 \pm 0.07^{\mathrm{c}}$ & $3.86 \pm 0.05^{\mathrm{B}}$ \\
\hline Valine & $2.87 \pm 0.15^{\mathrm{a}}$ & $5.78 \pm 0.29^{\mathrm{A}}$ & $2.70 \pm 0.10^{\mathrm{a}}$ & $6.25 \pm 0.03^{\mathrm{AB}}$ & $1.70 \pm 0.28^{\mathrm{b}}$ & $6.89 \pm 0.56^{\mathrm{B}}$ \\
\hline Methionine & $0.53 \pm 0.32$ & $1.05 \pm 0.57$ & $0.47 \pm 0.15$ & $1.09 \pm 0.37$ & $0.30 \pm 0.00$ & $1.22 \pm 0.11$ \\
\hline Isoleucine & $2.40 \pm 0.26^{\mathrm{a}}$ & $4.82 \pm 0.17$ & $2.10 \pm 0.10^{\mathrm{a}}$ & $4.86 \pm 0.05$ & $1.10 \pm 0.14^{b}$ & $4.46 \pm 0.19$ \\
\hline Leucine & $3.67 \pm 0.32^{\mathrm{a}}$ & $7.37 \pm 0.14^{\mathrm{A}}$ & $3.23 \pm 0.15^{\mathrm{a}}$ & $7.48 \pm 0.12^{\mathrm{A}}$ & $1.70 \pm 0.14^{\mathrm{b}}$ & $6.91 \pm 0.02^{\mathrm{B}}$ \\
\hline Phenylalanine & $2.20 \pm 0.17^{\mathrm{a}}$ & $4.42 \pm 0.12$ & $2.03 \pm 0.12^{\mathrm{a}}$ & $4.71 \pm 0.13$ & $1.15 \pm 0.07^{b}$ & $4.68 \pm 0.12$ \\
\hline Histidine & $2.70 \pm 0.20^{\mathrm{a}}$ & $5.43 \pm 0.08^{\mathrm{A}}$ & $2.43 \pm 0.06^{\mathrm{a}}$ & $5.64 \pm 0.13^{\mathrm{A}}$ & $1.90 \pm 0.14^{\mathrm{b}}$ & $7.73 \pm 0.09^{\mathrm{B}}$ \\
\hline Lysine & $4.13 \pm 0.38^{\mathrm{a}}$ & $8.31 \pm 0.19^{\mathrm{A}}$ & $3.47 \pm 0.21^{\mathrm{a}}$ & $8.02 \pm 0.23^{\mathrm{A}}$ & $1.80 \pm 0.14^{b}$ & $7.32 \pm 0.06^{\mathrm{B}}$ \\
\hline Arginine & $2.73 \pm 0.21^{\mathrm{a}}$ & $5.50 \pm 0.05^{\mathrm{A}}$ & $2.30 \pm 0.17^{\mathrm{a}}$ & $5.32 \pm 0.26^{\mathrm{A}}$ & $1.10 \pm 0.14^{\mathrm{b}}$ & $4.46 \pm 0.19^{\mathrm{B}}$ \\
\hline Total essential & $23.37 \pm 1.96^{\mathrm{a}}$ & $46.78 \pm 0.32$ & $20.50 \pm 0.85^{\mathrm{a}}$ & $47.45 \pm 0.44$ & $11.70 \pm 1.13^{\mathrm{b}}$ & $47.54 \pm 0.50$ \\
\hline \multicolumn{7}{|l|}{ Non-essential } \\
\hline Aspartic acid & $5.10 \pm 0.46^{a}$ & $10.25 \pm 0.10$ & $4.20 \pm 0.20^{\mathrm{b}}$ & $9.72 \pm 0.11$ & $2.25 \pm 0.21^{\mathrm{c}}$ & $9.14 \pm 0.07$ \\
\hline Serine & $2.60 \pm 0.17^{a}$ & $5.23 \pm 0.15$ & $2.37 \pm 0.12^{\mathrm{a}}$ & $5.48 \pm 0.16$ & $1.30 \pm 0.14^{\mathrm{b}}$ & $5.28 \pm 0.12$ \\
\hline Glutamic acid & $7.50 \pm 0.62^{\mathrm{a}}$ & $15.08 \pm 0.15^{\mathrm{A}}$ & $6.17 \pm 0.21^{\mathrm{b}}$ & $14.28 \pm 0.20^{\mathrm{B}}$ & $3.50 \pm 0.42^{c}$ & $14.21 \pm 0.5^{\mathrm{B}}$ \\
\hline Proline & $2.33 \pm 0.23^{\mathrm{a}}$ & $4.69 \pm 0.29$ & $1.83 \pm 0.06^{\mathrm{b}}$ & $4.25 \pm 0.10$ & $1.00 \pm 0.14^{\mathrm{c}}$ & $4.06 \pm 0.23$ \\
\hline Glycine & $2.20 \pm 0.20^{\mathrm{a}}$ & $4.42 \pm 0.07^{\mathrm{A}}$ & $1.87 \pm 0.12^{\mathrm{a}}$ & $4.32 \pm 0.16^{\mathrm{A}}$ & $0.95 \pm 0.07^{b}$ & $3.86 \pm 0.05^{\mathrm{B}}$ \\
\hline Alanine & $2.43 \pm 0.21^{\mathrm{a}}$ & $4.89 \pm 0.05^{\mathrm{A}}$ & $2.00 \pm 0.10^{\mathrm{b}}$ & $4.63 \pm 0.06^{\mathrm{B}}$ & $1.05 \pm 0.07^{\mathrm{c}}$ & $4.27 \pm 0.08^{\mathrm{C}}$ \\
\hline Cysteine & $2.40 \pm 0.10$ & $4.84 \pm 0.39^{\mathrm{A}}$ & $2.70 \pm 0.44$ & $6.26 \pm 1.02^{\mathrm{AB}}$ & $2.05 \pm 0.21$ & $8.40 \pm 1.59^{\mathrm{B}}$ \\
\hline Tyrosine & $1.80 \pm 0.20^{\mathrm{a}}$ & $3.61 \pm 0.12$ & $1.57 \pm 0.06^{\mathrm{a}}$ & $3.63 \pm 0.05$ & $0.80 \pm 0.14^{\mathrm{b}}$ & $3.24 \pm 0.30$ \\
\hline Total non-essential & $26.37 \pm 2.06^{\mathrm{a}}$ & $53.02 \pm 0.32$ & $22.70 \pm 0.79^{a}$ & $52.55 \pm 0.44$ & $12.90 \pm 0.99^{b}$ & $52.46 \pm 0.50$ \\
\hline Total & $49.73 \pm 4.33^{\mathrm{a}}$ & & $43.20 \pm 2.47^{\mathrm{a}}$ & & $24.60 \pm 2.55^{\mathrm{b}}$ & \\
\hline
\end{tabular}

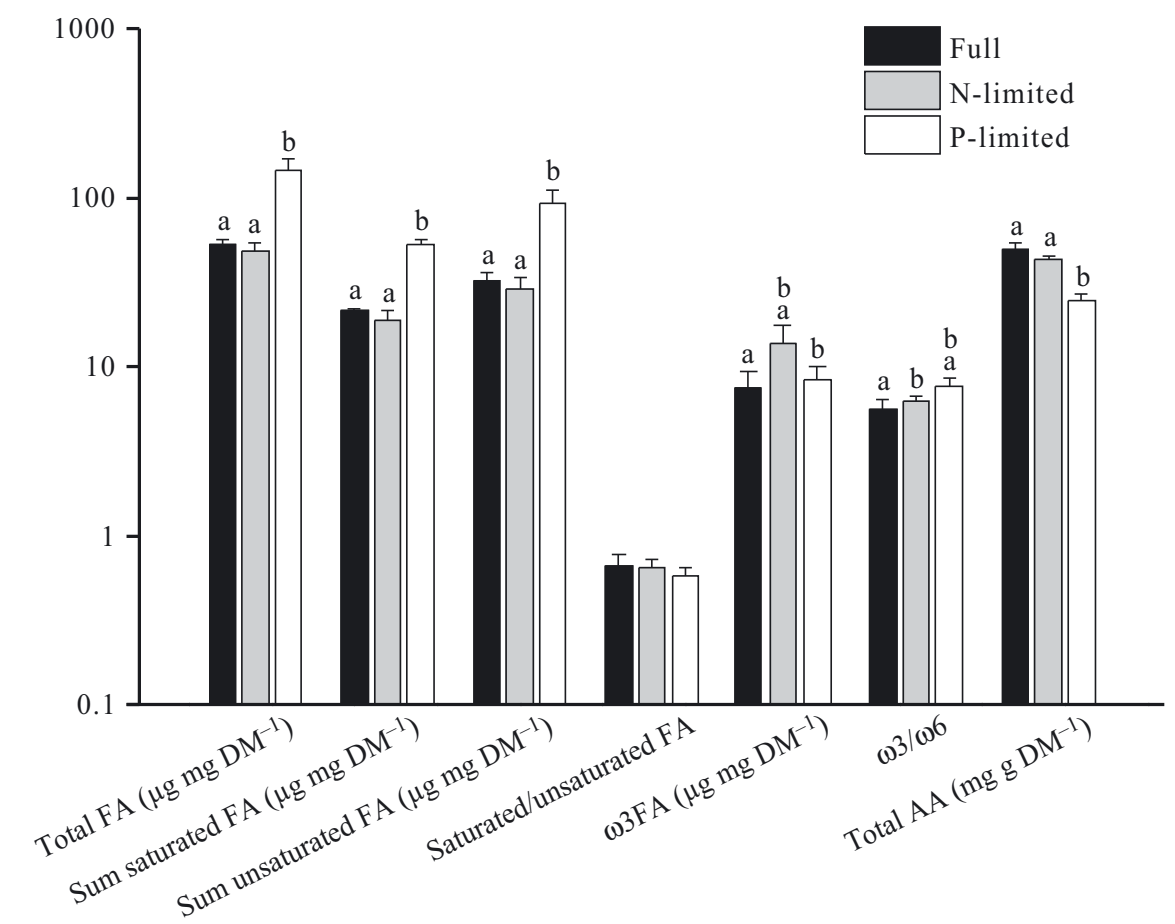

Fig. 2. Summary of several aggregated indicators related to fatty acid (FA) and amino acid (AA) content of Brachionus plicatilis reared on phytoplankton Chlorella vulgaris grown under 3 different nutrient conditions. Error bars: SD. Different letters above columns indicate significant difference among the 3 treatments (Tukey's HSD test, $\mathrm{p}<0.05$ ). DM: dry mass. Note the $y$-axis 
Table 3. Fatty acid (FA) composition (mean \pm SD) of Brachionus plicatilis reared on phytoplankton Chlorella vulgaris grown under 3 different nutrient conditions. Values represent the means of 3 replicate samples and are listed in $\mu g$ per mg dry mass (DM) and \% of total FA content. Significant differences (Tukey's HSD test or Kruskal-Wallis $H$ test, $p<0.05$ ) among the 3 treatments indicated by different superscripted lowercase (for DM) or uppercase letters (for \% of total FA content)

\begin{tabular}{|c|c|c|c|c|c|c|}
\hline & \multicolumn{2}{|c|}{ Full } & \multicolumn{2}{|c|}{ N-limited } & \multicolumn{2}{|c|}{ P-limited } \\
\hline & $\mu g \mathrm{mg} \mathrm{DM}^{-1}$ & $\%$ of total & $\mu \mathrm{g} m g \mathrm{DM}^{-1}$ & $\%$ of total & $\mu g \mathrm{mg} \mathrm{DM}^{-1}$ & $\%$ of total \\
\hline $\mathrm{C} 12: 0$ & $0.23 \pm 0.08^{\mathrm{ab}}$ & $0.42 \pm 0.16$ & $0.12 \pm 0.03^{a}$ & $0.25 \pm 0.04$ & $0.33 \pm 0.04^{b}$ & $0.22 \pm 0.01$ \\
\hline $\mathrm{C} 14: 0$ & $3.14 \pm 0.18^{\mathrm{a}}$ & $5.86 \pm 0.48^{\mathrm{A}}$ & $2.03 \pm 0.32^{\mathrm{a}}$ & $4.21 \pm 0.23^{\mathrm{B}}$ & $6.97 \pm 0.86^{b}$ & $4.78 \pm 0.21^{\mathrm{B}}$ \\
\hline C15:0 & $0.29 \pm 0.02^{\mathrm{a}}$ & $0.55 \pm 0.05^{\mathrm{A}}$ & $0.11 \pm 0.05^{b}$ & $0.22 \pm 0.09^{\mathrm{B}}$ & $0.27 \pm 0.04^{\mathrm{a}}$ & $0.18 \pm 0.00^{\mathrm{B}}$ \\
\hline $\mathrm{C} 16: 0$ & $14.19 \pm 0.7^{\mathrm{a}}$ & $26.53 \pm 2.62$ & $12.72 \pm 1.94^{\mathrm{a}}$ & $26.41 \pm 2.3$ & $34.55 \pm 2.57^{\mathrm{b}}$ & $23.79 \pm 2.17$ \\
\hline C16:1 & $19.39 \pm 1.35^{a}$ & $36.11 \pm 0.53^{\mathrm{A}}$ & $15.68 \pm 2.55^{\mathrm{a}}$ & $32.46 \pm 0.78^{\mathrm{B}}$ & $58.08 \pm 10.81^{b}$ & $39.62 \pm 0.84^{\mathrm{C}}$ \\
\hline C18:0 & $2.42 \pm 0.28^{\mathrm{a}}$ & $4.54 \pm 0.76$ & $2.34 \pm 0.44^{\mathrm{a}}$ & $4.88 \pm 0.93$ & $6.76 \pm 0.14^{b}$ & $4.69 \pm 0.87$ \\
\hline C18:1 & $3.76 \pm 0.28^{\mathrm{a}}$ & $7.00 \pm 0.30^{\mathrm{A}}$ & $3.72 \pm 0.61^{\mathrm{a}}$ & $7.69 \pm 0.19^{B}$ & $17.37 \pm 2.92^{\mathrm{b}}$ & $11.87 \pm 0.04^{\mathrm{C}}$ \\
\hline $\mathrm{C} 18: 2 \omega 6$ & $1.13 \pm 0.14^{\mathrm{a}}$ & $2.10 \pm 0.13^{\mathrm{A}}$ & $0.73 \pm 0.11^{\mathrm{a}}$ & $1.51 \pm 0.04^{\mathrm{B}}$ & $1.80 \pm 0.29^{b}$ & $1.23 \pm 0.00^{\mathrm{C}}$ \\
\hline $\mathrm{C} 20: 0$ & $0.18 \pm 0.12^{\mathrm{a}}$ & $0.35 \pm 0.23$ & $0.29 \pm 0.34^{\mathrm{a}}$ & $0.66 \pm 0.84$ & $2.30 \pm 0.31^{b}$ & $1.57 \pm 0.05$ \\
\hline $\mathrm{C} 20: 3 \omega 6$ & $0.18 \pm 0.08$ & $0.33 \pm 0.13^{\mathrm{A}}$ & $0.36 \pm 0.06$ & $0.74 \pm 0.05^{\mathrm{B}}$ & $0.40 \pm 0.20$ & $0.27 \pm 0.09^{\mathrm{A}}$ \\
\hline $\mathrm{C} 20: 3 \omega 3$ & $1.61 \pm 0.43$ & $2.97 \pm 0.65^{\mathrm{AB}}$ & $1.99 \pm 0.39$ & $4.12 \pm 0.46^{\mathrm{A}}$ & $2.46 \pm 0.63$ & $1.67 \pm 0.16^{\mathrm{B}}$ \\
\hline $\mathrm{C} 20: 5 \omega 3$ & $5.90 \pm 1.61$ & $10.90 \pm 2.40$ & $6.45 \pm 1.33$ & $13.38 \pm 1.83$ & $11.46 \pm 3.31$ & $7.75 \pm 0.98$ \\
\hline $\mathrm{C} 22: 1 \omega 9$ & $0.28 \pm 0.20$ & $0.52 \pm 0.38$ & $0.21 \pm 0.05$ & $0.43 \pm 0.06$ & $1.53 \pm 1.59$ & $0.97 \pm 0.93$ \\
\hline $\mathrm{C} 24: 0$ & $0.99 \pm 0.31$ & $1.82 \pm 0.48^{\mathrm{A}}$ & $1.47 \pm 0.31$ & $3.05 \pm 0.44^{\mathrm{B}}$ & $2.08 \pm 0.75$ & $1.40 \pm 0.28^{\mathrm{A}}$ \\
\hline Total FA & $53.70 \pm 3.45^{\mathrm{a}}$ & & $48.20 \pm 6.71^{\mathrm{a}}$ & & $146.36 \pm 24.17^{\mathrm{b}}$ & \\
\hline Sum saturated & $21.45 \pm 1.00^{\mathrm{a}}$ & $40.07 \pm 3.69$ & $19.07 \pm 2.39^{\mathrm{a}}$ & $39.67 \pm 2.78$ & $53.25 \pm 4.42^{\mathrm{b}}$ & $36.63 \pm 3.03$ \\
\hline Sum unsaturated & $32.25 \pm 3.86^{\mathrm{a}}$ & $59.93 \pm 3.69$ & $29.13 \pm 4.85^{\mathrm{a}}$ & $60.33 \pm 2.78$ & $93.11 \pm 19.75^{b}$ & $63.37 \pm 3.03$ \\
\hline $\begin{array}{l}\text { Saturated: } \\
\text { unsaturated ratio }\end{array}$ & $0.67 \pm 0.11$ & $0.67 \pm 0.11$ & $0.66 \pm 0.08$ & $0.66 \pm 0.08$ & $0.58 \pm 0.08$ & $0.58 \pm 0.08$ \\
\hline$\omega 3$ & $7.51 \pm 2.04$ & $13.87 \pm 3.04^{\mathrm{AB}}$ & $8.44 \pm 1.72$ & $17.50 \pm 2.29^{\mathrm{A}}$ & $13.92 \pm 3.94$ & $9.42 \pm 1.14^{\mathrm{B}}$ \\
\hline$\omega 6$ & $1.31 \pm 0.21^{\mathrm{a}}$ & $2.43 \pm 0.24^{\mathrm{A}}$ & $1.08 \pm 0.17^{a}$ & $2.25 \pm 0.08^{\mathrm{A}}$ & $2.20 \pm 0.49^{b}$ & $1.50 \pm 0.09^{\mathrm{B}}$ \\
\hline$\omega 3: \omega 6$ ratio & $5.66 \pm 0.85^{\mathrm{a}}$ & $5.66 \pm 0.85^{\mathrm{A}}$ & $7.77 \pm 0.76^{b}$ & $7.77 \pm 0.76^{\mathrm{B}}$ & $6.27 \pm 0.40^{\mathrm{ab}}$ & $6.27 \pm 0.40^{\mathrm{AB}}$ \\
\hline
\end{tabular}

\section{Elemental homeostasis}

Among the 3 treatments, the nutrient composition and molar ratios of the fish larvae showed similar patterns to that of the rotifers (Fig. 1). For example, larvae in the $-\mathrm{F}$ treatment showed the highest value of $\% \mathrm{C}$, followed by the $-\mathrm{N}$ treatment, and the $-\mathrm{P}$ treatment, which had the lowest value (50.02 for $-\mathrm{F}$, 39.66 for $-\mathrm{N}$, and 28.20 for $-\mathrm{P}$; Fig. 1a). For the rotifers, the $\% \mathrm{C}$ showed the same pattern as that of the larvae (43.91 for $-\mathrm{F}, 36.69$ for $-\mathrm{N}$, and 30.50 for -P; Fig. 1a). However, compared with fish larvae, the stoichiometry of the jellyfish ephyrae showed patterns that were inconsistent with that of the rotifers.
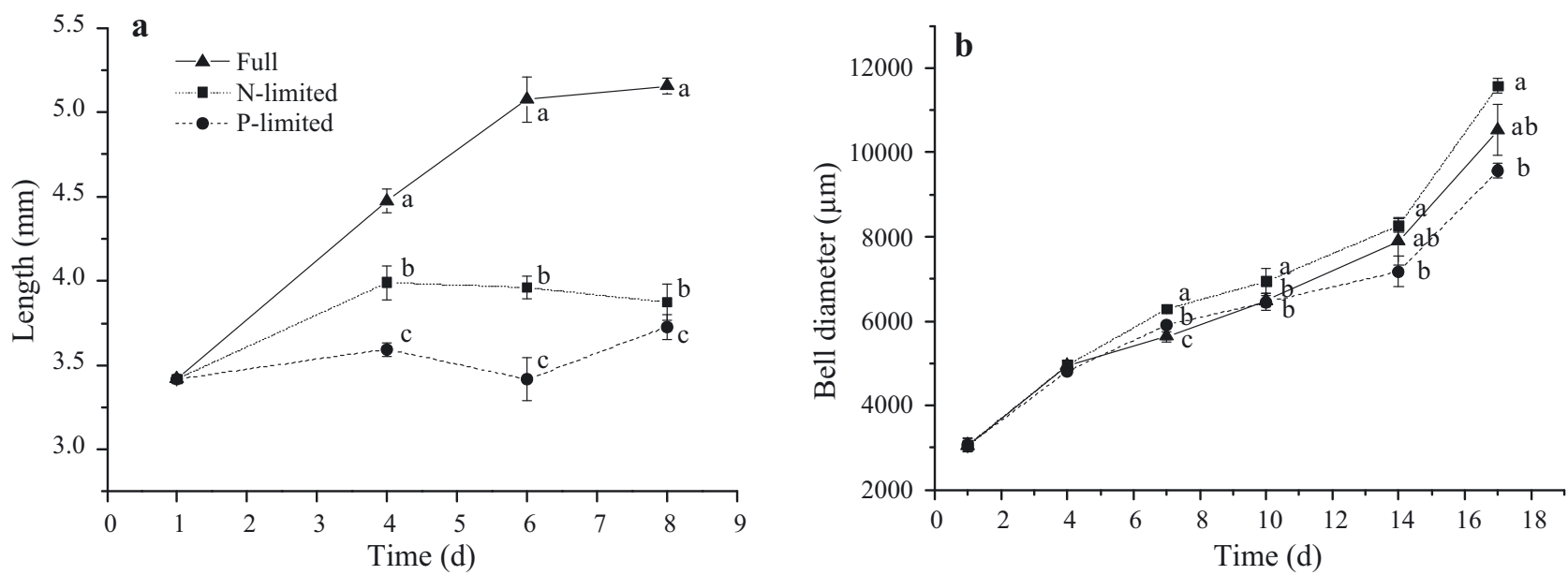

Fig. 3. Changes in (a) length of Paralichthys olivaceus larvae and (b) bell diameter of Aurelia sp. 1 ephyrae fed Brachionus plicatilis reared under nutrient-sufficient (Full), N-limited, and P-limited conditions. Error bars: SD. Significant differences (Fisher's HSD test, $\mathrm{p}<0.05$ ) among the 3 treatments indicated by different lowercase letters 


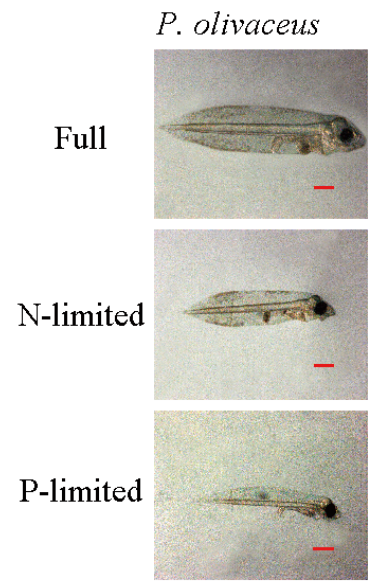

Day 8
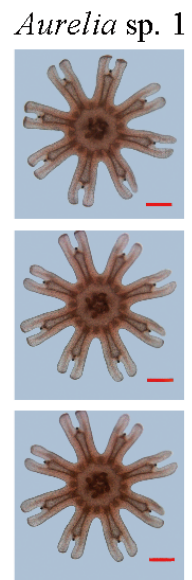

Day 1

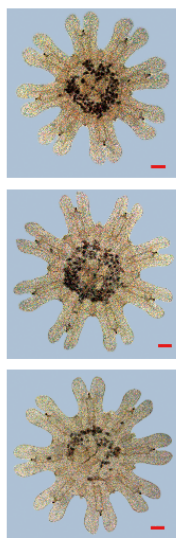

Day 7

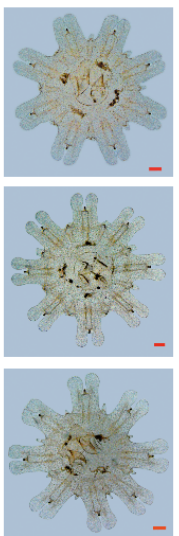

Day 10
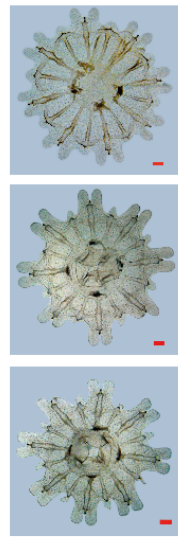

Day 14
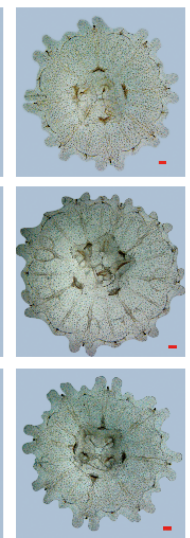

Day 17

Fig. 4. Morphological status of Paralichthys olivaceus larvae on the last day and of Aurelia sp. 1 ephyrae during the experimental period when fed food with different nutrient conditions. All scale bars $=500 \mu \mathrm{m}$
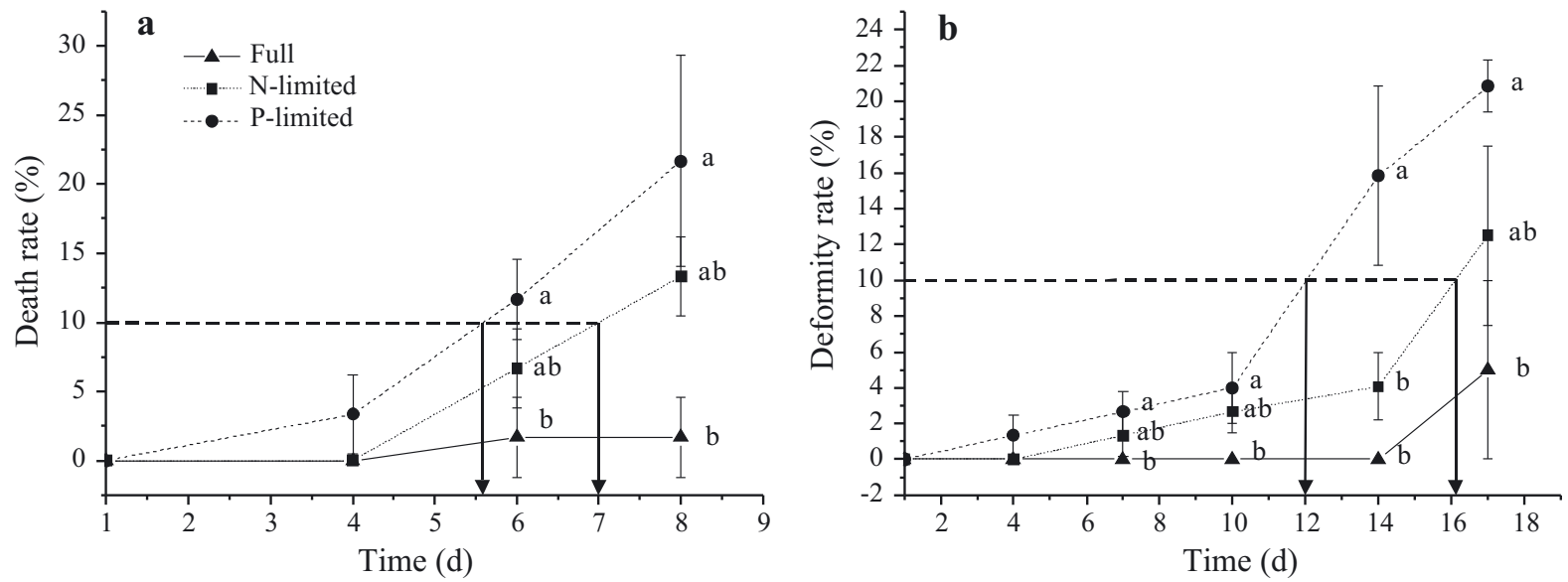

Fig. 5. (a) Death rate of Paralichthys olivaceus larvae and (b) deformity rate of Aurelia sp. 1 ephyrae when fed food of different nutrient conditions. Error bars: SD. Significant differences (Fisher's HSD test, $p<0.05$ ) among the 3 treatments indicated by different lowercase letters. The 10th percentile mortality time (MT10, arrows) is the time span at which 10\% (dashed line) of the larvae died or ephyrae deformed

Table 4. Homeostatic regulation coefficient $(H)$ (see Eqs. 1 \& 2) and parameters calculated from linear regression for each stoichiometric composition (e.g. \% $, \mathrm{N}: \mathrm{P}$, etc.) of secondary consumers (Paralichthys olivaceus larvae and Aurelia sp. 1 ephyrae). Results with $\mathrm{R}^{2}<0$ were excluded

\begin{tabular}{|c|c|c|c|c|c|}
\hline \multicolumn{2}{|c|}{ Stoichiometry } & Slope $(1 / H)$ & $\log (C)$ & $\mathrm{R}^{2}$ & $H$ \\
\hline \multirow{5}{*}{ P. olivaceus } & $\% \mathrm{C}$ & 1.226 & -0.319 & 0.999 & 0.846 \\
\hline & $\% \mathrm{P}$ & 2.945 & 0.100 & 0.975 & 0.340 \\
\hline & $\% \mathrm{~N}$ & 1.001 & 0.030 & 0.999 & 0.999 \\
\hline & $\mathrm{C}: \mathrm{N}$ & 0.763 & 0.135 & 0.981 & 1.311 \\
\hline & $\mathrm{C}: \mathrm{P}$ & -3.174 & 9.017 & 0.101 & -0.315 \\
\hline \multirow[t]{5}{*}{ Aurelia sp. 1} & $\% \mathrm{C}$ & -0.27 & 1.44 & 0.803 & -3.76 \\
\hline & $\% \mathrm{P}$ & -1.30 & -0.88 & 0.114 & -0.77 \\
\hline & $\% \mathrm{~N}$ & -0.27 & 0.68 & 0.758 & -3.70 \\
\hline & $\mathrm{C}: \mathrm{N}$ & -0.35 & 0.93 & 0.171 & -2.86 \\
\hline & $\mathrm{N}: \mathrm{P}$ & -0.87 & 2.40 & 0.079 & -1.14 \\
\hline
\end{tabular}

With regards to the homeostatic regulation coefficient $H$, for each stoichiometric component (e.g. N:P, \%P, etc.), the absolute value of the Aurelia sp. 1 ephyrae $H$ was higher than that of the $P$. olivaceus larvae, and the $1 / H$ (slope) of the Aurelia sp. 1 ephyrae was much closer to zero than that of the $P$. olivaceus larvae (Table 4 ). For example, the $1 / H_{\% \mathrm{C}}$ value of the fish larvae differed from 0 by 1.23 , whereas that of the Aurelia sp. 1 ephyrae differed by only 0.27 . The $P$. olivaceus larvae $1 / H_{\mathrm{C}: \mathrm{N}}$ value was 0.76 , and the absolute $1 / H_{\mathrm{C}: \mathrm{N}}$ value of the Aurelia sp. 1 ephyrae was only 0.35 (Table 4). 


\section{DISCUSSION}

\section{Different responses of fish larvae and jellyfish ephyrae}

In our study, nutrient limitations, especially $\mathrm{P}$ limitation, showed strong negative effects on the growth conditions of Paralichthys olivaceus larvae (Figs. 1, 4 \& 5). These observations could be attributed to the characteristics of fish larvae, which have a high demand for nutrients and low tolerance to nutrient limitations compared to jellyfish. The P content of the fish body (P of DM) increased sharply during the larval and early juvenile stages, which was mostly because of bone formation (Pilati \& Vanni 2007). In addition to the ossification of bones, the growth of muscle and development of fin rays in the larval stage also promoted an increase in P contents (Malzahn et al. 2007). This ontogenetic increase in $P$ in fish larvae resulted in a high demand for nutrients, thus leading to the low tolerance to nutrient limitations. Therefore, under a diet with lower $\mathrm{P}$ content ( $0.51 \%$ in the $-\mathrm{P}$ treatment), the growth conditions of $P$. olivaceus larvae were poor, whereas the growth conditions were improved under a diet with a higher P content $(0.73 \%$ in the Full treatment) (Figs. 1 \& $3-5)$. This finding is consistent with that of Vielma et al. (2002), who demonstrated that when the dietary $P$ content increased from $0.50 \%$ to $0.75 \%$, the specific growth rate $\left(\% \mathrm{~d}^{-1}\right)$ of European whitefish fingerlings (Coregonus lavaretus L.) rapidly increased.

However, nutrient limitations had little negative effect on the Aurelia sp. 1 ephyrae, since no significant differences were detected between the Full treatment and the P-limited treatment, and the $\mathrm{N}$ limited treatment always produced a greater bell diameter than the other 2 treatments (Fig. 3b). Schoo et al. (2010) also found that P-limited copepods represented a food source of higher quality for ctenophores Pleurobrachia pileus, and Malzahn et al. (2010) demonstrated that nutrient limitations did not affect the growth conditions of limnomedusae Gonionemus vertens. These studies and our results imply that jellyfish may not be negatively affected by nutrient limitations as compared to P. olivaceus larvae.

Limited studies are available on the effect of nutrient limitations on marine jellyfish (e.g. Malzahn et al. 2010, Schoo et al. 2010, Lesniowski et al. 2015), and thus, we can only speculate on the physiological processes underlying the above results. Ontogenetic changes in the elemental composition of Aurelia sp. 1 and $P$. olivaceus implied that they had different nutrient demands. From our results, the $\mathrm{N}$ content of newly released Aurelia sp. 1 ephyrae (fed with newly hatched Artemia nauplii) was $8.72 \% \mathrm{DM}$ and the C content was $37.46 \%$ DM (Fig. 1b). Meanwhile, Ikeda (2014) reported much lower values for Aurelia aurita (the same genus as Aurelia sp. 1) medusae with an $\mathrm{N}$ content of approximately $1.30 \% \mathrm{DM}$ and a C content of approximately $4.30 \% \mathrm{DM}$, indicating that the C and $\mathrm{N}$ content decreased considerably with ontogenesis. However, Pilati \& Vanni (2007) found that the body P content in fish (both Dorosoma cepedianum and Danio rerio) increased considerably during the life cycle. These differences in how stoichiometry changes with ontogeny imply that there might be a lower nutrient demand in Aurelia sp. 1 than in fish. This could be attributed to the jellyfish body plan. The jellyfish body primarily contains mesoglea, an extracellular matrix consisting of water, salts, and collagen fibers (Verde \& McCloskey 1998), which decreases the concentration of $\mathrm{N}$ and $\mathrm{P}$. In addition to predation, jellyfish could acquire nutrients through the uptake of dissolved sources (Pitt et al. 2009) which are abundant in coastal regions. Although it could account for only $<10 \%$ of the metabolic requirements of non-zooxanthellate jellyfish (Ferguson 1982), the uptake of limiting elements from dissolved sources could provide an advantage to alleviate the nutrient imbalance of the food. In general, the C:nutrient values of the prey under the condition of altered nutrient ratios were higher than those under the Redfield ratio, implying an excess of $\mathrm{C}$ in the prey (Sterner \& Elser 2002). For jellyfish medusae, the excess $C$ could be excreted as mucus and dissolved organic matter (Condon et al. 2011, Pitt et al. 2013), and this strategy might mitigate the nutrient imbalance of the food resources as well. As limited studies are available and the above statements are mostly speculations, more research is needed to explore the physiological processes underlying the high tolerance of Aurelia sp. 1 to nutrient limitation. Meanwhile, research on coastal and open-ocean species is also needed to determine whether the high tolerance of Aurelia sp. 1 is consistent with the gelatinous body plan.

In terms of the homeostasis of the organisms, our results showed that for each stoichiometric composition (e.g. N:P, \%P, etc.), the $1 / H$ (slope) of the Aurelia sp. 1 ephyrae was much closer to zero than that of the P. olivaceus larvae (Fig. 1, Table 4). Because a slope $(1 / H)$ of zero represents homeostasis (Sterner \& Elser 2002), the above results imply that Aurelia sp. 1 ephyrae had a greater ability to maintain stable chemical compositions within their bodies compared with the $P$. olivaceus larvae. Thus, compared with $P$. olivaceus larvae, the chemical compositions of the Aurelia sp. 1 ephyrae were less likely to be affected 
by nutrient limitations. Because elemental homeostasis plays an important role for jellyfish and weaker homeostasis would have negative consequences (e.g. lower growth rate) (Sterner \& Elser 2002), Aurelia sp. 1 ephyrae could be more competitive than P. olivaceus larvae in terms of homeostasis.

\section{Biochemical compositions and food quality}

Nutrient limitation is known to be reflected by alterations of the biochemical composition (e.g. FA content) (Sterner \& Elser 2002). In our experiments, the rotifers in the P-limited treatment produced significantly higher FA contents than those in the other treatments, and similar phenomena have been reported in other organisms under nutrient-limited conditions, exhibiting higher FA content (Boersma 2000, Klausmeier et al. 2004a, Malzahn et al. 2007, Boersma et al. 2009). Siron et al. (1989) stated that the enhanced FA contents exhibited in P-limited treatments could be attributed to $C$ storage in response to an imbalanced nutrient supply (suboptimal growth condition). Because the FA saturation threshold may be low for most zooplankton species (Becker \& Boersma 2005), the growth of $P$. olivaceus larvae may not be negatively affected by the lowest FA contents among the 3 treatments or the highest FA content of the P-limited treatment. As eicosapentaenoic acid (EPA) (C20:5 $\omega 3)$ and $\omega 3 \mathrm{FA}$ are beneficial to growth, reproduction, and other factors (Harrison 1990, Lee et al. 2000), they have typically been used to assess food quality. However, in our experiments, the Full treatment yielded the best growth condition with the highest growth rate and the highest MT10 value (Figs. $3-5$ ) but the lowest EPA content (C20:5 03 ) and $\omega 3 \mathrm{FA}$, and the lowest $\omega 3: \omega 6$ ratio (Fig. 2, Table 3). Therefore, FA contents may not provide a reasonable explanation for the lower food quality of organisms raised under the P-limited treatment.

With regard to amino acids, our results indicated that rotifers in the P-limited treatment provided the lowest content (Table 3, Fig. 2). This result had the same pattern as the growth conditions of $P$. olivaceus larvae among the 3 treatments (lowest growth rate and MT10 value in the P-limited treatment; Figs. 3-5). These results suggest that under nutrient-limited conditions, the growth conditions of $P$. olivaceus larvae could be tightly coupled to the amino acid contents of rotifers (P. olivaceus larvae food).

Many studies have examined the importance of amino acid contents to the growth of fish larvae. A reduction in amino acid contents affects fish larvae, es- pecially at the start of exogenous feeding (Rønnestad et al. 1999, Park et al. 2000, Wright \& Fyhn 2001, Alam et al. 2002, Kim et al. 2003, Aragão et al. 2004). In the early stages, the larval digestive system is not fully developed, and complex proteins are not easily digested (Rønnestad et al. 1999, Aragão et al. 2004, Naz \& Türkmen 2009). Because the free amino acid (FAA) content could be absorbed by fish larvae rapidly and efficiently (Alam et al. 2001, Applebaum \& Rønnestad 2004, Ohkubo et al. 2008), the FAAs were essential for fish larvae. In addition, the FAA content provided important building blocks for protein synthesis (Rønnestad et al. 2003), and higher contents of amino acids in the food could increase the amount of trypsin secretion, thus contributing to protein digestion (Cahu \& Infante 1995, Jobgen et al. 2006, Kim et al. 2007). In addition, amino acids were identified as one of the major energy sources for firstfeeding larvae (Wright \& Fyhn 2001, Rønnestad et 2003, Brown et al. 2005). In addition to FAA, the soluble proteins, which constituted approximately $50 \%$ of the total proteins (Srivastava et al. 2006), were expected to be more available for uptake by pinocytosis and digestion by intestinal proteases relative to the total proteins (Carvalho et al. 2004). Once the soluble proteins were digested, their amino acids could be readily absorbed by fish larvae. These physiological processes resulted in the constant consumption and high demand of amino acids from the food. In our experiment, rotifers are the food source of $P$. olivaceus larvae, and rotifers in the P-limited treatments offered significantly lower contents of amino acids than those in the Full treatment (Table 3, Fig. 2). This result implied that the amino acid content of rotifers under Plimited conditions did not meet the needs of $P$. olivaceus larvae, which negatively affected the growth of $P$. olivaceus larvae. Therefore, the content of amino acids could be a good predictor of food quality.

\section{CONCLUSIONS}

Our experiments indicated that nutrient limitations had stronger negative effects on Paralichthys olivaceus larvae than they did on Aurelia sp. 1 ephyrae, based on growth, survival, and elemental homeostasis of the organisms, suggesting that jellyfish ephyrae could be more competitive than fish larvae under nutrient-limited conditions. The reduction in amino acid content had negative effects on growth and survival of $P$. olivaceus larvae, which implied that this parameter may be a good predictor of food quality in nutrient-limited environments. 
Acknowledgements. This study was supported by the National Natural Science Foundation of China (41476139), the NSFC-Shandong Joint Fund for Marine Ecology and Environmental Sciences (U1406403), and the National Basic Research Program of China (2011CB403604). We gratefully acknowledge Yongqiang Shi for recommending references about eutrophication and jellyfish blooms. We thank Guang Yang and Li Zhou for polishing and commenting on the revised version of the manuscript. Gratitude is extended to anonymous reviewers for critical and useful comments.

\section{LITERATURE CITED}

Alam MS, Teshima S, Ishikawa M, Koshio S, Yaniharto D (2001) Methionine requirement of juvenile Japanese flounder Paralichthys olivaceus estimated by the oxidation of radioactive methionine. Aquacult Nutr 7:201-209

Alam MS, Teshima S, Koshio S, Ishikawa M (2002) Arginine requirement of juvenile Japanese flounder Paralichthys olivaceus estimated by growth and biochemical parameters. Aquaculture 205:127-140

Andersen T, Elser JJ, Hessen DO (2004) Stoichiometry and population dynamics. Ecol Lett 7:884-900

Applebaum SL, Rønnestad I (2004) Absorption, assimilation and catabolism of individual free amino acids by larval Atlantic halibut (Hippoglossus hippoglossus). Aquaculture 230:313-322

Aragão C, Conceição LE, Dinis MT, Fyhn HJ (2004) Amino acid pools of rotifers and Artemia under different conditions: nutritional implications for fish larvae. Aquaculture 234:429-445

Arai MN (2001) Pelagic coelenterates and eutrophication: a review. Hydrobiologia 451:69-87

Becker C, Boersma M (2005) Differential effects of phosphorus and fatty acids on Daphnia magna growth and reproduction. Limnol Oceanogr 50:388-397

Boersma M (2000) The nutritional quality of P-limited algae for Daphnia. Limnol Oceanogr 45:1157-1161

Boersma M, Becker C, Malzahn AM, Vernooij S (2009) Food chain effects of nutrient limitation in primary producers. Mar Freshw Res 60:983-989

Breitburg DL, Adamack A, Rose KA, Kolesar SE and others (2003) The pattern and influence of low dissolved oxygen in the Patuxent River, a seasonally hypoxic estuary. Estuaries 26:280-297

Brown MR, Battaglene SC, Morehead DT, Brock M (2005) Ontogenetic changes in amino acid and vitamins during early larval stages of striped trumpeter (Latris lineata). Aquaculture 248:263-274

* Cahu C, Infante JZ (1995) Effect of the molecular form of dietary nitrogen supply in sea bass larvae: response of pancreatic enzymes and intestinal peptidases. Fish Physiol Biochem 14:209-214

* Carvalho A, Sá R, Oliva-Teles A, Bergot P (2004) Solubility and peptide profile affect the utilization of dietary protein by common carp (Cyprinus carpio) during early larval stages. Aquaculture 234:319-333

Chen L, Li C (2014) Research advances in ecological stoichiometry of marine plankton. Chin J Appl Ecol 25: 3047-3055

Conceição L, Grasdalen H, Rønnestad I (2003) Amino acid requirements of fish larvae and post-larvae: new tools and recent findings. Aquaculture 227:221-232

Condon RH, Steinberg DK, del Giorgio PA, Bouvier TC,
Bronk DA, Graham WM, Ducklow HW (2011) Jellyfish blooms result in a major microbial respiratory sink of carbon in marine systems. Proc Natl Acad Sci USA 108: 10225-10230

Flser JJ, Fagan WF, Denno RF, Dobberfuhl DR and others (2000) Nutritional constraints in terrestrial and freshwater food webs. Nature 408:578-580

* Elser JJ, Hayakawa K, Urabe J (2001) Nutrient limitation reduces food quality for zooplankton: Daphnia response to seston phosphorus enrichment. Ecology 82:898-903

Ferguson JC (1982) A comparative study of the net metabolic benefits derived from the uptake and release of free amino acids by marine invertebrates. Biol Bull (Woods Hole) 162:1-17

*Fukuda Y, Matsuoka S, Mizuno Y, Narita K (1996) Pasteurella piscicida infection in cultured juvenile Japanese flounder. Fish Pathol 31:33-38

*Goldman JC, McCarthy JJ, Peavey DG (1979) Growth-rate influence on the chemical composition of phytoplankton in oceanic waters. Nature 279:210-215

*Hall SR, Smith VH, Lytle DA, Leibold MA (2005) Constraints on primary producer N:P stoichiometry along N:P supply ratio gradients. Ecology 86:1894-1904

Harrison KE (1990) The role of nutrition in maturation, reproduction and embryonic development of decapod crustaceans: a review. J Shellfish Res 9:1-28

* Howarth RW, Sharpley A, Walker D (2002) Sources of nutrient pollution to coastal waters in the United States: implications for achieving coastal water quality goals. Estuaries 25:656-676

Ikeda T (2014) Synthesis toward a global model of metabolism and chemical composition of medusae and ctenophores. J Exp Mar Biol Ecol 456:50-64

Ishii H, Kojima S, Tanaka Y (2004) Survivorship and production of Aurelia aurita ephyrae in the innermost part of Tokyo Bay, Japan. Plankton Biol Ecol 51:26-35

Jobgen WS, Fried SK, Fu WJ, Meininger CJ, Wu G (2006) Regulatory role for the arginine-nitric oxide pathway in metabolism of energy substrates. J Nutr Biochem 17: 571-588

Kattner G, Hagen W, Lee RF, Campbell R and others (2007) Perspectives on marine zooplankton lipids. Can J Fish Aquat Sci 64:1628-1639

Kim SK, Takeuchi T, Yokoyama M, Murata Y (2003) Effect of dietary supplementation with taurine, beta-alanine and GABA on the growth of juvenile and fingerling Japanese flounder Paralichthys olivaceus. Fish Sci 69:242-248

Kim SK, Matsunari H, Takeuchi T, Yokoyama M, Murata Y, Ishihara K (2007) Effect of different dietary taurine levels on the conjugated bile acid composition and growth performance of juvenile and fingerling Japanese flounder Paralichthys olivaceus. Aquaculture 273:595-601

K Klausmeier CA, Litchman E, Daufresne T, Levin SA (2004a) Optimal nitrogen-to-phosphorus stoichiometry of phytoplankton. Nature 429:171-174

Klausmeier CA, Litchman E, Levin SA (2004b) Phytoplankton growth and stoichiometry under multiple nutrient limitation. Limnol Oceanogr 49:1463-1470

*Kütter VT, Wallner-Kersanach M, Sella SM, Albuquerque ALS, Knoppers BA, Silva-Filho EV (2014) Carbon, nitrogen, and phosphorus stoichiometry of plankton and the nutrient regime in Cabo Frio Bay, SE Brazil. Environ Monit Assess 186:559-573

* Lee SM, Cho SH, Kim KD (2000) Effects of dietary protein and energy levels on growth and body composition of 
juvenile flounder Paralichthys olivaceus. J World Aquacult Soc 31:306-315

Lesniowski TJ, Gambill M, Holst S, Peck MA and others (2015) Effects of food and $\mathrm{CO}_{2}$ on growth dynamics of polyps of two scyphozoan species (Cyanea capillata and Chrysaora hysoscella). Mar Biol 162:1371-1382

Liu M, Li C, Sun S (2011) Seasonal variation in fatty acid composition of seston and the copepod Calanus sinicus (Brodsky, 1962) in Jiaozhou Bay and its trophic implications. Chin J Oceanol Limnol 29:1164-1173

Malzahn AM, Aberle N, Clemmesen C, Boersma M (2007) Nutrient limitation of primary producers affects planktivorous fish condition. Limnol Oceanogr 52:2062-2071

Malzahn AM, Hantzsche F, Schoo KL, Boersma M, Aberle N (2010) Differential effects of nutrient-limited primary production on primary, secondary or tertiary consumers. Oecologia 162:35-48

Müller-Navarra DC (1995) Biochemical versus mineral limitation in Daphnia. Limnol Oceanogr 40:1209-1214

Naz M, Türkmen M (2009) The changes in digestive enzymes and hormones of gilthead seabream larvae (Sparus aurata, L 1758) fed on Artemia nauplii enriched with free methionine. Aquacult Int 17:243-256

Nixon SW (1995) Coastal marine eutrophication: a definition, social causes, and future concerns. Ophelia 41: $199-219$

* Ohkubo N, Sawaguchi S, Nomura K, Tanaka H, Matsubara $\mathrm{T}$ (2008) Utilization of free amino acids, yolk protein and lipids in developing eggs and yolk-sac larvae of Japanese eel Anguilla japonica. Aquaculture 282:130-137

Park GS, Takeuchi T, Seikai T, Yoshinaga T (2000) The effects of residual salts and free amino acids in mysid meal on growth of juvenile Japanese flounder Paralichthys olivaceus. Bull Jpn Soc Sci Fish 66:697-704

Pilati A, Vanni MJ (2007) Ontogeny, diet shifts, and nutrient stoichiometry in fish. Oikos 116:1663-1674

* Pitt KA, Welsh DT, Condon RH (2009) Influence of jellyfish blooms on carbon, nitrogen and phosphorus cycling and plankton production. Hydrobiologia 616:133-149

* Pitt KA, Duarte CM, Lucas CH, Sutherland KR and others (2013) Jellyfish body plans provide allometric advantages beyond low carbon content. PLOS ONE 8:e72683

Purcell JE, Arai MN (2001) Interactions of pelagic cnidarians and ctenophores with fishes: a review. Hydrobiologia 451:27-44

Purcell JE, Uye S, Lo WT (2007) Anthropogenic causes of jellyfish blooms and their direct consequences for humans: a review. Mar Ecol Prog Ser 350:153-174

Reitan KI, Rainuzzo JR, Øie G, Olsen Y (1997) A review of the nutritional effects of algae in marine fish larvae. Aquaculture 155:207-221

Rhee GY (1978) Effects of N:P atomic ratios and nitrate limitation on algal growth, cell composition, and nitrate uptake. Limnol Oceanogr 23:10-25

Editorial responsibility: Robert Condon, Wilmington, North Carolina, USA
Rønnestad I, Thorsen A, Finn RN (1999) Fish larval nutrition: a review of recent advances in the roles of amino acids. Aquaculture 177:201-216

* Rønnestad I, Tonheim SK, Fyhn HJ, Rojas-García CR and others (2003) The supply of amino acids during early feeding stages of marine fish larvae: a review of recent findings. Aquaculture 227:147-164

Schoo KL, Aberle N, Malzahn AM, Boersma M (2010) Does the nutrient stoichiometry of primary producers affect the secondary consumer Pleurobrachia pileus? Aquat Ecol 44:233-242

* Schoo KL, Aberle N, Malzahn AM, Boersma M (2012) Food quality affects secondary consumers even at low quantities: an experimental test with larval European lobster. PLOS ONE 7:e33550

Schoo KL, Aberle N, Malzahn AM, Schmalenbach I, Boersma M (2014) The reaction of European lobster larvae (Homarus gammarus) to different quality food: effects of ontogenetic shifts and pre-feeding history. Oecologia 174:581-594

Siron R, Giusti G, Berland B (1989) Changes in the fatty acid composition of Phaeodactylum tricornutum and Dunaliella tertiolecta during growth and under phosphorus deficiency. Mar Ecol Prog Ser 55:95-100

* Srivastava A, Hamre K, Stoss J, Chakrabarti R, Tonheim SK (2006) Protein content and amino acid composition of the live feed rotifer (Brachionus plicatilis): with emphasis on the water soluble fraction. Aquaculture 254:534-543

Sterner RW, Elser JJ (2002) Ecological stoichiometry: the biology of elements from molecules to the biosphere. Princeton University Press, Princeton, NJ

Uye S (1994) Replacement of large copepods by small ones with eutrophication of embayments: cause and consequence. Hydrobiologia 292:513-519

*Van Nieuwerburgh L, Wänstrand I, Snoeijs P (2004) Growth and C: N: P ratios in copepods grazing on N- or Si-limited phytoplankton blooms. Hydrobiologia 514:57-72

*Verde EA, McCloskey L (1998) Production, respiration, and photophysiology of the mangrove jellyfish Cassiopea xamachana symbiotic with zooxanthellae: effect of jellyfish size and season. Mar Ecol Prog Ser 168:147-162

* Vielma J, Koskela J, Ruohonen K (2002) Growth, bone mineralization, and heat and low oxygen tolerance in European whitefish (Coregonus lavaretus L.) fed with graded levels of phosphorus. Aquaculture 212:321-333

Wan A, Zhang G (2012) Annual occurrence of moon jellyfish Aurelia sp.1 in the Jiaozhou Bay and its impacts on zooplankton community. Oceanol Limnol Sin 43:494-501

Wright P, Fyhn H (2001) Ontogeny of nitrogen metabolism and excretion. Fish Physiol 20:149-200

Wu H, Ruan H, Wang X, Wu P, Cheng G, Yang W (1987) Studies on the ecological basis of resources multiplication and stocking experiment on the false halibut, Paralichthys olivaceus in Jiaozhou Bay. Mar Sci 6:52-53

Submitted: February 3, 2016; Accepted: March 7, 2017

Proofs received from author(s): April 3, 2017 